
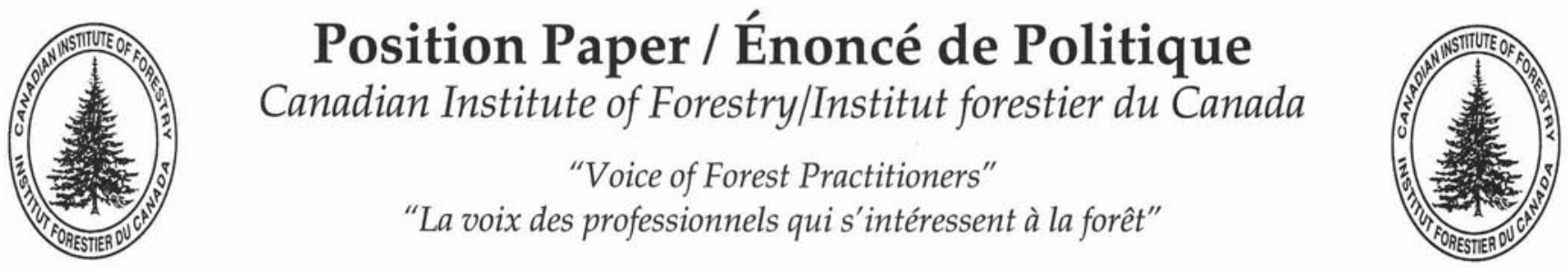

\title{
Policy Statement on Forest Certification Systems Enoncé de politique sur les systèmes de certification forestière
}

\begin{abstract}
Background
Certification is a market-based, voluntary activity designed to demonstrate that forest operations are being managed according to a recognized standard that presumes resource sustainability. It assumes that consumer interest in forests is strong and that these same consumers will discriminate in favour of wood products originating from forests they believe are being managed according to sustainable principles. In this regard, certification has the potential to become a key factor in the international trade of forest products.

Canada is a forest nation and forests cover nearly $50 \%$ of the landscape or 417.6 million hectares. Of the forested land, 235 million hectares are considered "commercial forests" capable of producing timber and non-timber products. To date only about 120 million hectares are managed, primarily for timber production. Canada's forests support numerous other industries including tourism, recreation, the fur trade, wild foods and maple products. Canada's forests also provide for an array of social, environmental and cultural benefits.

Canada has embraced the concept of sustainable forest management (SFM). Members of the forest community have clearly stated a commitment to SFM by being signatories to the Canada Forest Accord (1998), which accompanied the renewed National Forest Strategy. Achieving SFM must be demonstrable both within Canada and to Canada's export partners. Certification has the capacity to verify that forest operations meet all the ecological, economic and social standards of the selected certification system. In this regard, the hectares of forested land registered/certified using the major certification processes available in Canada continue to grow.
\end{abstract}

\section{Issues}

Several issues that relate to certification processes include the following:

1. Although there are major certification processes operating in Canada, there are numerous other processes operating worldwide. Ultimately, there needs to be some rationalization of these processes for similar forest types. At a minimum, there is a requirement for mutual recognition and/or equivalency of the different standards by the various systems.

2. Affordable certification processes, at the proper scale, are required for small landholdings. Group processes are available for the International Standards Organization (ISO), Canadian Standards Association (CSA) and Forest Stewardship Council (FSC) systems. However, they all require an umbrella organization or group co-operative to act on behalf of each landowner.

\section{Le contexte}

La certification est une activité volontaire, issue des marchés, conçue pour démontrer que les opérations forestières sont effectuées selon une norme reconnue qui présume la durabilité de la ressource. On assume que l'intérêt du consommateur est marqué et que ces mêmes consommateurs feront une discrimination entre les produits forestiers en provenance des forêts qu'ils croient être aménagées selon des principes de durabilité. À cet effet, la certification a la possibilité de devenir un facteur-clé au niveau du commerce international des produits forestiers.

Le Canada est une nation forestière dont les forêts couvrent près de $50 \%$ de son territoire, soit 417.6 millions d'hectares. De ce territoire forestier, 235 millions d'hectares sont considérées comme étant des « forêts commerciales » capables de produire du bois et des produits non-ligneux. À ce jour, seulement 120 millions d'hectares sont aménagés, principalement pour la production de bois. Les forêts canadiennes sont à la base de plusieurs autres industries, dont le tourisme, les loisirs, le commerce des fourrures, les aliments prélevés en forêt et les produits de l'érable. Les forêts du Canada procurent également une multitude de bénéfices sociaux, environnementaux et culturels.

Le Canada s'est rallié au concept de l'aménagement forestier durable (AFD). Les membres de la communauté forestière ont clairement déclaré leur engagement envers l'AFD en signant l'Entente sur les forêts du Canada (1998), qui accompagnait le renouvellement de la Stratégie forestière du Canada. L'atteinte de l'AFD doit être démontrée tant au Canada que pour les partenaires commerciaux du Canada. La certification a la capacité de vérifier que les opérations forestières répondent à toutes les normes écologiques, économiques et sociales du système retenu de certification. À cet effet, les hectares de territoires forestiers inscrits/certifiés selon les principaux processus de certification disponible au Canada continuent d'augmenter.

\section{Les enjeux}

Parmi les enjeux reliés aux processus de certification, on retrouve les suivant :

1. Même si les principaux processus de certification sont présents au Canada, il existe plusieurs autres processus en vigueur dans le monde. En bout de ligne, il faut qu'il ait une certaine rationalisation de ces processus pour des types de forêts semblables. Au minimum, il est requis d'établir une reconnaissance mutuelle ou encore une équivalence des différentes normes utilisées par ces nombreux systèmes. 
3. Landscape-level issues, such as the need to designate a percentage of the land base as "protected area," cannot always be resolved through certification processes at the forest management unit scale. Resolution of these issues may require government action through land use planning.

4. The methods for auditor accreditation are significantly different among the certification systems. Registration of an Environmental Management System under ISO, or Registration of a Defined Forest Area under CSA, are achieved following a successful third-party audit by a Registrar who has been accredited by the Standards Council of Canada. Certification of a forest management unit under the FSC is achieved following a successful third-party audit by a certifying body accredited by the FSC. Therefore, under the ISO and CSA, standards development processes and auditor accreditation are quite separate, while both of these processes are under the control of the FSC organization.

5. Concerning product logos, the main issues relate to:

- Chain of custody;

- Use of recycled fibres or materials; and

- Partial incorporation of non-certified wood into certified products.

The FSC has a policy on minimum percentage requirements and labelling directions in the use of their logo on certified wood products.

6. Certification (or rather its absence) has the potential to become a non-tariff trade barrier. Thus, rather than certified wood products filling a specialized product niche, or having producers receive a premium price for certified wood products, the result may be a loss of market share for those producers whose operations and products are not certified.

\section{The CIF/IFC and Certification}

Certification is poised to become a critical factor in successfully demonstrating SFM in Canada. As such, CIF/IFC endorses the concept of certification and advocates the continued use and development of certification systems. In this regard, the CIF/IFC will:

1. As a signatory to the Canada Forest Accord, continue to work toward implementation of SFM in Canada.

2. Recognize that voluntary certification systems are an act of good faith relative to the pursuit of SFM.

3. Support the position that any certification system used in Canada must abide by respective jurisdictional legislation, regulations, standards, policies and practices.

4. Recognize and promote the notion that certification is a voluntary decision to be undertaken by forest owners/managers and that barriers to achieving certification (including costs) should not exist under any system.

5. Encourage interested parties to obtain all information available on the various certification systems when they make their decision to pursue certification.

6. Encourage governments to support the concept of certification by:

- Participating in certification activities where required as a landowner, licence grantor, regulator and/or forest manager.

- Managing landscape-level issues, which cannot be resolved at the forest management unit level.

- Conveying to Canada's trading partners the degree and extent of SFM practised in Canada's forests and the extent of successful forest certification in the country.
2. Des processus de certification à prix raisonnable et à une échelle adéquate sont requis pour les petites propriétés. Des processus de groupe sont disponible au niveau des systèmes de l'Organisation internationale de la normalisation (ISO), de l'Association canadienne de normalisation (CSA) et du Forest Stewardship Council (FSC). Toutefois, ils requièrent tous un organisme parapluie ou un groupe coopératif pour agir au nom de chaque propriétaire.

3. Les questions au niveau des paysages, tel le besoin de désigner un pourcentage du territoire comme "zone protégée », ne peuvent être toujours résolues par les processus de certification agissant à l'échelle de l'unité d'aménagement forestier. La résolution de ces questions pourrait nécessiter l'intervention gouvernementale au moyen de la planification de l'utilisation du territoire.

4. Les méthodes d'accréditation des vérificateurs sont significativement différentes entre les systèmes de certification. L'inscription d'un Système de gestion environnementale selon ISO, ou l'inscription de Territoires forestiers définis sous la CSA, est atteinte suite à la vérification réussie effectuée par une tierce partie qui se trouve à être un registraire agréé par le Conseil canadien de normalisation. La certification d'une unité d'aménagement forestier selon le FSC est réalisée suite à la vérification réussie par une tierce partie qui est un organisme de certification agréé par le FSC. En conséquence, selon l'ISO et la CSA, les processus d'élaboration des normes et l'agrément des vérificateurs sont deux choses distinctes, tandis que ces deux processus sont sous le contrôle de l'organisme FSC.

5. Au sujet des logos des produits, les principales questions sont relatives à :

- La chaîne de fabrication

- L'utilisation de fibres ou de matériaux recyclés; et

- L'incorporation partielle de bois non-certifié dans les produits certifiés.

Le FSC a une politique de seuil minimal et des directives d'étiquetage au sujet de l'utilisation de leur logo sur les produits de bois certifié.

6. La certification (ou plutôt son absence) pourrait devenir une barrière non tarifaire au commerce. En conséquence, plutôt que d'obtenir des produits de bois certifié correspondant à une niche d'un produit spécialisé, ou d'avoir des producteurs qui reçoivent un prix majoré pour les produits de bois certifié, le résultat pourrait être une perte d'une part du marché pour les producteurs dont les opérations et les produits ne sont pas certifiés.

\section{Le CIF/IFC et la certification}

La certification est sur le point de devenir un facteur déterminant de la démonstration réussie de l'AFD au Canada. En tant que tel, l'Institut endosse le concept de certification et plaide pour l'utilisation continue et le développement des systèmes de certification. À cet effet, l'Institut :

1. Poursuivra, en tant que signataire de l'Entente sur les forêts du Canada, de voir à l'implantation de l'AFD au Canada.

2. Reconnaitra les systèmes de certification volontaire comme étant un geste de bonne foi envers la poursuite de l'AFD.

3. Supportera la position que tout système de certification utilisé au Canada doit respecter les législations, les règlements, les normes, les politiques et les pratiques de chaque juridiction. 
7. Encourage rationalization of certification standards for similar forest types and the pursuit of mutual recognition and/or equivalency of the different certification standards.

8. Inform interested parties about certification through a range of communication tools.

9. Monitor and report on the progress of SFM certification across Canada.

\section{Who We Are}

The Canadian Institute of Forestry/Institut forestier du Canada (CIF/IFC) is a national voice for forestry practitioners. The CIF/IFC, formed in 1908, has over 2500 members organized in 23 sections across Canada representing members who are scientists, academics, technicians, technologists, and foresters with an interest in the well-being of the forest. The Institute's mission is "to provide national leadership in forestry, promote competence among forestry professionals, and foster public awareness of Canadian and international forestry issues."

Canadian Institute of Forestry/Institut forestier du Canada 151 Slater Street, Suite 606

Ottawa Ontario K1P 5H3

Telephone: 613-234-2242

Facsimile: 613-234-6181

Email: cif@cif-ifc.org

Internet: http://www.cif-ifc.org

This CIF/IFC Policy was prepared by Dr. David Balsillie through the CIF/IFC Standing Committee on Policy Development. The CIF/IFC gratefully acknowledges the comments of external reviewers in preparing this paper.

January 9, 2001
4. Reconnaîtra et fera la promotion que la certification est une décision volontaire qui doit être prise par les propriétaires/aménagistes forestiers et qu'aucune barrière empêchant l'atteinte de la certification (incluant les coûts) ne devrait exister sous aucun système.

5. Encouragera les parties impliquées à obtenir toutes les informations disponibles sur les différents systèmes de certification lorsqu'elles prennent la décision d'obtenir une certification.

6. Encouragera les gouvernements à appuyer le concept de certification au moyen :

- De la participation à des activités de certification lorsque requis en tant que propriétaire, attribuer de licence, de régulateur ou d'aménagiste forestier.

- De la gestion des questions d'aménagement au niveau du paysage, qui ne peuvent être résolues au niveau de l'unité d'aménagement forestier.

- De confirmer aux partenaires commerciaux du Canada le degré et l'étendu de l'AFD pratiqué dans les forêts canadiennes et le niveau de certification forestière réussie au Canada.

7. Encouragera la rationalisation des normes de certification des types de forêts semblables et la poursuite de la reconnaissance mutuelle ou encore des équivalences entre les différentes normes de certification.

8. Informera les parties intéressées sur la certification au moyen de plusieurs modes de communication.

9. Surveillera et fera rapport sur le progrès de la certification en AFD dans tout le Canada.

\section{Ce que nous sommes}

Le Canadian Institute of Forestry / Institut forestier du Canada (CIF/IFC) est le porte-parole national des praticiens de la foresterie. L'Institut, établi en 1908, compte plus de 2500 membres répartis en 23 sections recouvrant tout le Canada, qui sont des chercheurs, des académiciens, des techniciens, des technologistes et des forestiers qui ont pour intérêt le mieux-être des forêts. La mission de l'Institut est «d'assumer un leadership national en foresterie, de promouvoir la compétence parmi les professionnels de la foresterie, et d'accrôttre la sensibilisation du public face aux questions forestières canadiennes et internationales. »

Canadian Institut of Forestry / Institut forestier du Canada

151 , rue Slater, Bureau 606

Ottawa, Ontario K1P 5H3

Téléphone : 613-234-2242

Télécopieur : 613-234-6181

courriel : cif(cif-ifc.org

Internet : http://www.cif-ifc.org

Cet énoncé du CIF/IFC a été préparé par le Dr David Balsillie par l'entremise du Comité permanent de l'Institut sur l'Élaboration de politiques. L'Institut remercie sincèrement les réviseurs externes pour leurs commentaires effectués au cours de l'élaboration de cet énoncé.

9 janvier 2001 